\title{
Effects of Passiflora edulis on the Metabolic Profile of Diabetic Wistar Rat Offspring
}

\author{
Sandra M. Barbalho, ${ }^{1,2}$ Débora C. Damasceno, ${ }^{3}$ Ana Paula Machado Spada, ${ }^{4}$ Ira Eliane dos R.N. Lima, \\ Adriano Cressoni Araújo, ${ }^{1,3}$ Elen Landgraf Guiguer, ${ }^{1}$ Karla Aparecida Martuchi, ${ }^{6}$ \\ Marie Oshiiwa, ${ }^{2}$ and Claudemir Gregorio Mendes ${ }^{1}$ \\ ${ }^{1}$ Faculty at the School of Medicine and Health Sciences, University of Marilia (UNIMAR), Marilia, São Paulo, Brazil. \\ ${ }^{2}$ Faculty of Technology and Foods of Marlia, Faculty of Technology (FATEC), Marilia, São Paulo, Brazil. \\ ${ }^{3}$ Institute of Biosciences; São Paulo State University Julio de Mesquita Filho (UNESP-Botucatu), Botucatu, São Paulo, Brazil. \\ ${ }^{4}$ Faculty at UNINOVE and SENAC, University of Sao Paulo (USP), São Paulo, Brazil. \\ ${ }^{5}$ Healthy Ministry, Regional Hospital of Sao Filipe, Fire Island, Cape Verde. \\ ${ }^{6}$ Nutrition Department, Frigorificos Bertin S/A, Lins, São Paulo, Brazil.
}

\begin{abstract}
Dry extract of the genus Passiflora has been shown to help control glycemia and lipid levels. The objective of this study was to evaluate the effects of passion fruit ( $P$. edulis) on the biochemical profile of offspring from diabetic rats. Diabetes was induced by streptozotocin. The diabetes group consisted of 10 rats with glucose levels greater than $200 \mathrm{mg} / \mathrm{dL}$; the nondiabetic (control) group consisted of 10 rats with glucose levels less than $120 \mathrm{mg} / \mathrm{dL}$. After the diagnosis of diabetes, the mating phase was started. By day 21 of pregnancy, the offspring were born; the dams were kept in individual cages with their offspring until the weaning period. The offspring were then divided into 4 groups ( $n=15$ each): G1 were offspring from control dams, G2 were offspring from treated nondiabetic dams, G3 were offspring from diabetic dams, and G4 were offspring from treated diabetic dams. For 30 consecutive days, G1 and G3 offspring were treated with vehicle (oral gavage) and G2 and G4 offspring were treated with passion fruit juice (oral gavage). After 30-day treatment, the animals were anesthetized and killed, and blood was drawn immediately for analysis of the biochemical profile (total cholesterol, high-density lipoprotein cholesterol, low-density lipoprotein cholesterol, triglycerides, and glucose). The G2 and G4 rats showed significantly reduced total cholesterol, triglyceride, and low-density lipoprotein cholesterol levels and an increased high-density lipoprotein cholesterol level. The use of passion fruit juice improved lipid profiles, suggesting that this plant may have beneficial effects in the prevention and treatment of dyslipidemias and hyperglycemia.
\end{abstract}

\section{KEY WORDS: • diabetes $\bullet$ dyslipidemias $\bullet$ glycemia $\bullet$ Passiflora edulis $\bullet$ rats}

\section{INTRODUCTION}

D IABETES Mellitus is an endocrine disease characterized by hyperglycemia. It results from total or partial deficiency of insulin production or the inability of this hormone to adequately exert its effects on target tissues. ${ }^{1}$

A gestation is considered diabetogenic when insulin resistance occurs with increased serum levels of estrogen, prolactin, progesterone, cortisol, and chorionic somatomammotropin in an attempt to maintain a constant supply of glucose for the fetus. Elevation of maternal glucose levels causes fetal hyperglycemia and hyperinsulinemia, leading to increased perinatal morbidity and mortality and affecting the synthesis of lipids and proteins. ${ }^{2-6}$

Diabetes mellitus causes approximately $10 \%$ of fetal malformations and is responsible for $40 \%$ of neonatal

Manuscript received 22 November 2010. Revision accepted 7 March 2011.

Address correspondence to: Sandra Maria Barbalho, Av. Sampaio Vidal, 300, apto. 24, Bairro Barboza, Marllia, São Paulo,Brazil,E-mail: smbarbalho@terra.com.br deaths. ${ }^{7-9}$ Live newborns may already have metabolic alterations and higher risk for future complications. Epidemiologic studies show that in pregnancy, the lack of strict maternal glycemic control changes fetal metabolism, which leads to higher risk for metabolic alterations in fetuses, both in the gestational period and throughout their lives. ${ }^{4,5} \mathrm{Ad}-$ ditionally, maternal hyperglycemia stimulates fetal growth (macrosomia) because of the greater availability of glucose in the bloodstream and by the regulation of growth factors. ${ }^{5,6,8}$ Greater weight at birth is related to the risk for developing insulin resistance, obesity, and type 2 diabetes mellitus in the future. ${ }^{10}$

Associated with diabetes mellitus are dyslipidemias, which are considered determining factors for the development of cardiovascular diseases. Elevated concentrations of plasma triglycerides, total cholesterol, and low-density lipoprotein (LDL) cholesterol along with decreased highdensity lipoprotein (HDL) cholesterol levels lead to a group of risk factors called the metabolic syndrome, which increases the risk for vascular diseases. ${ }^{10,11}$ 
The treatment of diabetes mellitus and its complications is costly, and people often seek less expensive alternatives, such as medicinal plants. Use of these plants is an ancient human practice.

Many studies have shown that plants can be used to control diabetes mellitus and hypercholesterolemia. Passiflora edulis (tangy passion fruit or maracuja) is a popular remedy for treating anxiety, epilepsy, headache, and abdominal pain. The dry extract of Passiflora helps control glycemia and lipid levels. Ramos showed that $P$. edulis can reduce total and LDL cholesterol levels and Doyama et al. showed that $P$. alata increases HDL cholesterol levels in rats at a dose of $1000 \mathrm{mg} / \mathrm{kg} .{ }^{12,13}$ Given the hypoglycemic effects of passion fruit, the objective of our study was to evaluate the effects of this plant on the biochemical profile of offspring of diabetic rats.

\section{MATERIALS AND METHODS}

\section{Parental generation}

Wistar rats were kept in the vivarium of Universidade Metodista de Piracicaba (Lins Campus), Brazil, under controlled conditions (12-hour/12-hour light/dark cycle, mean ambient temperature \pm standard deviation of $22^{\circ} \mathrm{C} \pm 2{ }^{\circ} \mathrm{C}$, relative humidity of $60 \% \pm 5 \%$, and water and chow ad libitum). Rats were treated according to the "Guide to the Care and Use of Experimental Animals" of the Canadian Council on Animal Care. The study was initiated after its approval by the ethics committee under registration number 2500000764/2007-47.

\section{Diabetes Induction}

Nondiabetic rats $(n=20)$ weighing approximately $250 \mathrm{~g}$ underwent a 7-day adaptation period in the room where the experiment was designed. After this period, randomly selected rats $(n=10)$ underwent intravenous administration (through the caudal vein) of $40 \mathrm{mg}$ of streptozotocin per $\mathrm{kg}$ (Sigma Chemical Co.) diluted in citrate buffer $(0.1 \mathrm{M}$; $\mathrm{pH}$, $4.5)$. Nondiabetic animals $(n=10)$ received only the vehicle (citrate buffer) in a volume that was equivalent to that of the diabetogenic drug. ${ }^{14}$ Blood glucose levels were measured by using a glucose meter (OneTouch Ultra, Johnson \& Johnson) 7 days after the induction of diabetes. As an inclusion criterion, rats were considered to be diabetic if the glucose level was greater than $200 \mathrm{mg} / \mathrm{dL}$ and nondiabetic if the glucose level was less than $120 \mathrm{mg} / \mathrm{dL}$.

\section{Mating period}

One week after diabetes induction, each of the 4 female rats was mated overnight to nondiabetic male rats. The morning in which sperm was found in the vaginal smear was designated gestational day $0 .{ }^{15,16}$

\section{Pregnancy period}

In the morning on days $0,7,14$, and 21 of pregnancy, a blood drop was collected from the caudal vein for glycemia measurement by using a glucose meter. By day 21 of pregnancy, after birth of offspring, the dams remained in individual cages with their offspring until the weaning period (21 days).

\section{Offspring}

After weaning, the offspring (60 males) were kept in collective cages until they reached adulthood. The adult animals, weighing approximately $250 \mathrm{~g}$, were divided into 4 experimental groups ( $n=15$ animals per group): G1 were offspring from nondiabetic dams treated with vehicle (water), G2 were offspring from nondiabetic dams treated with $P$. edulis (passion fruit) juice, G3 were offspring from diabetic dams treated with vehicle (water), and G4 were offspring from diabetic dams treated with $P$. edulis juice. The juice and the vehicle were administered by oral gavage.

The animals in groups $\mathrm{G} 2$ and $\mathrm{G} 4$ received passion fruit juice at a dose of $0.58 \mathrm{~g} / \mathrm{kg}$ once a day (early morning) for 30 consecutive days. The dose administered to the animals was based on $200 \mathrm{~g} / \mathrm{L}$, which corresponds to the daily intake of $200 \mathrm{~mL}$ of juice by an adult man weighing $70.0 \mathrm{~kg}$ (this amount was based on folk medicine consultation about preparing the juice). Animals in the control group received a similar volume of water.

\section{Passion fruit juice preparation}

Passion fruits were obtained from Agricultural Cooperative of Lins-SP (COALINS). They were washed and cut, and the pulp was weighed $(200 \mathrm{~g} / \mathrm{L})$ and triturated with water in a blender for 1 minute. The juice was filtered and frozen in amber flasks. The preparation of the juice was based on folk medicine consultation. Each flask was thawed daily at ambient temperature 2 hours before administration.

\section{Blood collection and determination of biochemical profile}

At the end of the treatment period (30 days), the animals were anesthetized with sodium pentobarbital $(150 \mathrm{mg} / \mathrm{kg})$ and killed. Blood samples were collected from the cava vein to determine the biochemical profile. The tests were performed according to the methods proposed by commercial kits: LABTEST (Lagoa Santa) for glycemia, total cholesterol, HDL cholesterol, and triglycerides and WIENER LAB for LDL cholesterol (values in $\mathrm{mg} / \mathrm{dL}$ ). The results were interpreted according to criteria established by the American Diabetes Association. ${ }^{1}$

\section{Statistical analysis}

Data were analyzed by using the Student $t$-test, and the level of significance adopted was 5\% (BIOESTAT 5.0).

\section{RESULTS}

Rats in group G3 (offspring from diabetic dams that received water) showed significantly higher glucose, cholesterol, and triglyceride levels and lower HDL cholesterol levels than group G1 (offspring from nondiabetic dams that received water) (Table 1). These data indicate that adult 
Table 1. Biochemical Profile from Nondiabetic Offspring Treated with Vehicle (G1) and Diabetic Offspring Treated with Vehicle (G3)

\begin{tabular}{|c|c|c|c|}
\hline \multirow[b]{2}{*}{ Variable } & \multicolumn{2}{|c|}{ Groups } & \multirow[b]{2}{*}{$P$ value } \\
\hline & G1 & G3 & \\
\hline Glucose & $60.7 \pm 11.9^{\mathrm{a}}$ & $88.9 \pm 11.6^{\mathrm{b}}$ & .0008 \\
\hline Cholesterol & $76.8 \pm 17.35^{\mathrm{a}}$ & $92.7 \pm 4.7^{\mathrm{b}}$ & .0469 \\
\hline Triglycerides & $119.9 \pm 12.4^{\mathrm{a}}$ & $149.0 \pm 12.5^{\mathrm{b}}$ & .04701 \\
\hline HDL cholesterol & $34.4 \pm 3.33^{\mathrm{a}}$ & $30.4 \pm 4.1^{\mathrm{b}}$ & .0175 \\
\hline LDL cholesterol & $65.0 \pm 19.5^{\mathrm{a}}$ & $84.5 \pm 17.1^{\mathrm{b}}$ & .0693 \\
\hline
\end{tabular}

Unless otherwise noted, values are expressed as mean \pm standard deviation.

${ }^{\mathrm{ab}}$ Mean values and standard deviation followed by same superscript letter do not differ between groups G1 and G3.

HDL, high-density lipoprotein; LDL, low-density lipoprotein.

offspring from diabetic mothers have higher glycemic and lipid profiles than the offspring from nondiabetic mothers.

Table 2 shows that offspring from nondiabetic dams treated with $P$. edulis juice (G2) had significantly decreased cholesterol, triglyceride, and LDL cholesterol levels and significantly increased HDL cholesterol levels compared with the offspring of nondiabetic dams that received water (G1). These results show that the use of $P$. edulis juice may have beneficial effects on the lipid profile of offspring from nondiabetic dams.

Rats in group G4 (offspring from diabetic dams treated with $P$. edulis) showed significantly reduced levels of glucose, cholesterol, triglycerides, and LDL cholesterol and increased HDL cholesterol values compared with rats in group G3 (offspring from diabetic dams that received water) (Table 3). The treatment with P. edulis decreased lipid and glucose levels in the offspring of diabetic mothers when compared with the offspring of diabetic mothers that received vehicle.

Table 4 shows that G4 (offspring from diabetic dams treated with $P$. edulis) had lower HDL cholesterol values than group G2 (offspring from nondiabetic dams treated with $P$. edulis). Glucose, cholesterol, triglyceride, and LDL cholesterol levels did not significantly differ between these groups.

Table 2. Biochemical Profile from Nondiabetic Offspring Treated with Vehicle (G1) and Nondiabetic Offspring Treated with Passion Fruit Juice (G2)

\begin{tabular}{lccc}
\hline & \multicolumn{2}{c}{ Groups } & \\
\cline { 2 - 3 } Variable & $G 1$ & $G 2$ & P value \\
\hline Glucose & $60.7 \pm 11.9^{\mathrm{a}}$ & $65.4+8.3^{\mathrm{a}}$ & .3276 \\
Cholesterol & $76.8 \pm 17.35^{\mathrm{a}}$ & $55.1+13.8^{\mathrm{b}}$ & .0011 \\
Triglycerides & $119.9 \pm 12.4^{\mathrm{a}}$ & $74.1+16.7^{\mathrm{b}}$ & .0326 \\
HDL cholesterol & $34.4 \pm 3.33^{\mathrm{a}}$ & $52.4+7.4^{\mathrm{b}}$ & .0000 \\
LDL cholesterol & $65.0 \pm 19.5^{\mathrm{a}}$ & $46.5+7.5^{\mathrm{b}}$ & .0327 \\
\hline
\end{tabular}

Unless otherwise noted, values are expressed as mean \pm standard deviation.

${ }^{\mathrm{ab}}$ Mean values and standard deviation followed by same superscript letter do not differ between groups G1 and G2.
Table 3. Biochemical Profile from Diabetic Offspring Treated with Vehicle (G3) and Diabetic Offspring Treated with Passion Fruit Juice (G4)

\begin{tabular}{lccr}
\hline & \multicolumn{2}{c}{ Groups } \\
\cline { 2 - 3 } Variable & $G 3$ & $G 4$ & P value \\
\hline Glucose & $88.9 \pm 11.6^{\mathrm{a}}$ & $66.9 \pm 8.8^{\mathrm{b}}$ & .0000 \\
Cholesterol & $92.7 \pm 4.7^{\mathrm{a}}$ & $54.1 \pm 24.8^{\mathrm{b}}$ & .0332 \\
Triglycerides & $149.0 \pm 12.5^{\mathrm{a}}$ & $72.9 \pm 29.3^{\mathrm{b}}$ & .0225 \\
HDL cholesterol & $30.4 \pm 4.1^{\mathrm{a}}$ & $34.7 \pm 3.3^{\mathrm{b}}$ & .0244 \\
LDL cholesterol & $84.5 \pm 17.1^{\mathrm{a}}$ & $54.2 \pm 14.1^{\mathrm{b}}$ & .0133 \\
\hline
\end{tabular}

Unless otherwise noted, values are expressed as mean \pm standard deviation.

${ }^{\mathrm{ab}}$ Mean values and standard deviation followed by same superscript letter do not differ between groups G3 and G4.

\section{DISCUSSION}

In this study, the adult offspring from diabetic dams had a higher glycemic profile than the offspring from normoglycemic dams. This finding indicates that maternal hyperglycemia is related to hyperglycemia or insulin resistance in the offspring when they are adults. Maayan-Metzger et al. ${ }^{3}$ showed that the main risk factors for developing hypoglycemia in the first day of life were large size for gestational age and maternal type 1 diabetes mellitus. The young offspring who were born to mothers with diabetes mellitus were heavier, large for their gestational age, and had more severe hypoglycemia in the first day of life compared with infants born to mothers with nonsevere diabetes mellitus.

The lipid profile of offspring from diabetic dams also showed higher mean values than that of the offspring from nondiabetic dams. This may indicate a risk for future alterations. Deviations in glycemia and dyslipidemias are risk factors for metabolic syndrome and vascular disorders. ${ }^{17}$

Our results suggest that passion juice can be helpful in the treatment or prevention of diabetes mellitus and its complications in the offspring of mothers with diabetes: The animals that received the juice had reductions in glycemia and lipid profile. Ramos et al. ${ }^{12}$ studied a flour made with passion fruit and also found beneficial effects on the lipid profile.

Table 4. Biochemical Profile from Nondiabetic Offspring Treated with Passion Fruit Juice (G2) and Diabetic Offrsping Treated with Passion Fruit Juice (G4)

\begin{tabular}{|c|c|c|c|}
\hline \multirow[b]{2}{*}{ Variable } & \multicolumn{2}{|c|}{ Groups } & \multirow[b]{2}{*}{$P$ value } \\
\hline & $G 2$ & G4 & \\
\hline Glucose & $65.4+8.3^{\mathrm{a}}$ & $66.9 \pm 8.8^{\mathrm{a}}$ & .3606 \\
\hline Cholesterol & $55.1+13.8^{\mathrm{a}}$ & $54.1 \pm 24.8^{a}$ & .0540 \\
\hline Triglycerides & $74.1+16.7^{\mathrm{a}}$ & $72.9 \pm 29.3^{\mathrm{a}}$ & .4576 \\
\hline HDL cholesterol & $52.4+7.4^{\mathrm{a}}$ & $34.7 \pm 3.3^{\mathrm{b}}$ & .0000 \\
\hline LDL cholesterol & $46.5+7.5^{\mathrm{a}}$ & $54.2 \pm 14.1^{\mathrm{a}}$ & .1578 \\
\hline
\end{tabular}

Unless otherwise noted, values are expressed as mean \pm standard deviation.

${ }^{\mathrm{ab}}$ Mean values and standard deviation followed by same superscript letter do not differ between groups G2 and G4. 
Other authors have observed biochemical benefits with use of plants. Bera et al. ${ }^{18}$ found that a polyherbal formulation composed of 8 medicinal plants that was used for the management of streptozotocin-induced diabetes in rats had antidiabetic effects. glibenclamide. Baviloni et al..$^{19}$ showed antihyperglycemic activity of stem-bark extract of Vatairea macrocarpa in the treatment of diabetic rats. Umar et al. ${ }^{20}$ observed that Tetracera scandens had antidiabetic efficacy in diabetic rats. Tao et al. ${ }^{21}$ showed significant reduction in glucose, cholesterol, and triglyceride levels by using a traditional antidiabetic formula prepared with many plants. Salahuddin and Jalalpure ${ }^{22}$ observed a reduction in blood glucose levels and a reduction in lipid profile after using extract of Curcumis trigonus in diabetic rats. Adeneye and Adeyemi ${ }^{23}$ and Daisy et al. ${ }^{24}$ found decreases in lipids and glycemia with use of Hunteria umbellate and isolated components of Gymnema sylvestre, respectively.

Many other studies showed benefits of plants in the biochemical profile of rats with streptozotocin- or aloxaninduced diabetes, such as Polymnia sonchifolia, ${ }^{25}$ conophylline-containing plant extract, ${ }^{26}$ fruits of Musa (Chenkadali), ${ }^{27}$ Artemisia sphaerocephala ${ }^{28}$ Lagenaria siceraria, ${ }^{29}$ and Allium sativum. ${ }^{30}$ Helmstädter and Schuster ${ }^{31}$ observed antidiabetic effects of Vaccinium myrtillus. Other studies also showed that certain plants have hypolipidemic effects (Coriandrum sativum, Mentha piperita, asparagus roots, Allanblackia floribunda, Ficus religiosa, and Amorphophalus konjac) and can be used to reduce biomarkers for heart disease (Origanum onites and berries). ${ }^{32-36}$

The use of passion fruit did not lead to a significant difference in the glycemic profile of the offspring of nondiabetic rats. This is a positive result because in the absence of glycidic disorders, there is no need for the reduction of glucose levels. In contrast, the offspring of diabetic mothers had a significantly reduced glycemic profile when treated with this plant. Ramos et al. ${ }^{12}$ also observed a reduction in glycemia with the use of $P$. edulis in individuals with altered glucose metabolism. These findings demonstrate that this plant can be used in the control of glycemia in patients at risk for developing diabetes mellitus and its complications (including vascular damage).

The positive effects of passion fruit may be related to the compounds in its pulp. Passiflora species are rich in pectin, minerals, carotenoids, vitamin $\mathrm{C}$, and flavonoids. Studies have shown that pectins can reduce total cholesterol, triglyceride, and LDL cholesterol levels and increase HDL cholesterol levels. ${ }^{38}$ Fibers might reduce plasma lipid levels by increasing the excretion of cholesterol and biliary acids in feces. This effect on lipids reduces vascular damage and heart disease. ${ }^{39-41}$ Yapo et al..$^{42}$ investigated the fiber content in $P$. edulis juice and found that the total dietary fiber from yellow passion fruit rind was greater than $73 \%$ dry matter, of which insoluble dietary fiber accounted for greater than $60 \%(\mathrm{w} / \mathrm{w})$. The method they used also revealed that nonstarch polysaccharides were the predominant components (approximately 70\%, w/w).

The antioxidant properties of vitamins and flavonoids are described as having positive effects in the treatment and prevention of dyslipidemias and hyperglycemia. ${ }^{43} P$. incarnata reportedly contains glycosyl flavonoids, ${ }^{44,45}$ and $P$. edulis has antioxidant ${ }^{46,47}$ and anti-inflammatory properties. ${ }^{48,49}$ These properties may explain its effects on glycemia and the lipid profile in the animals we studied. The antioxidant compounds of $P$. edulis are 16 apigenin or luteolin derivatives, which include 4 mono-C-glycosyl, 8 O-glycosyl-C-glycosyl, and 4 O-glycosyl derivatives. Moreover, the uncommon C-deoxyhexosyl derivatives of luteolin and apigenin have been identified. ${ }^{50}$

\section{CONCLUSION}

The use of $P$. edulis improved the lipid and glycemic profile of offspring from diabetic and nondiabetic mothers of Wistar rats. This result suggests that this plant has potential as an adjuvant in the prevention and treatment of dyslipidemia and hyperglycemia. However, the effects in humans must be studied. Passion fruit, which is widely consumed, is easy to find at accessible prices, making it potentially interesting for medicinal purposes.

\section{ACKNOWLEDGMENT}

We thank Universidade Metodista de Piracicaba, São Paulo, Brazil, for allowing us to conduct this research.

\section{AUTHOR DISCLOSURE STATEMENT}

No competing financial interests exist.

\section{REFERENCES}

1. American Diabetes Association: 2010. www.diabetes.org/ diabetes-basics/type-2/?utm_source $=$ WWW \&utm_medium $=$ DropDownDB\&utm_content $=$ Type $2 \& u t m \_$campaign $=$CON , acessed April 14, 2011.

2. Padilha C, Saunders C, Machado RCM, et al.: Association between pre-gestational nutritional status and prediction of the risk of adverse pregnancy outcome. Braz Arch Endocrinol Metabol 2007;29:511-518.

3. Maayan-Metzger A, Lubin D, Kuint J: Hypoglycemia rates in the first days of life among term infants born to diabetic mothers. Neonatology 2009;96:80-85.

4. Nomura RMY, Costa VN, Sakamoto K, et al.: Computerized cardiotocography in pregnancies complicated by pregestational diabetes mellitus: heart rate patterns in large for gestational age fetuses. Braz J Gynecol Obstet 2005;27:712-718.

5. Tanus LRM, Oliveira DS, Matheus ASM, Cunha EF, Gomes MB: Early infancy onset of type 1a diabetes mellitus in dizygotic twins: association with genetic and environmental factors. Braz Arch Endocrinol Metabol 2007;51:142-145.

6. Persson B: Neonatal glucose metabolism in offspring of mothers with varying degrees of hyperglycemia during pregnancy. Semin Fetal Neonat Med 2009;14:106-110.

7. Rudge MVC, Calderon IMP: The obstetrician ethical responsibility in the diagnosis and treatment of gestational diabetes mellitus (GDM). Braz J Gynecol Obstet 2006;571574 .

8. Arteaga J, Luna L, Mutchinick OM: Diabetes, pregnancy and birth defects. Invest Clin 2008;60:107-114. 
9. Basu A, Du M, Sanchez K, et al.: Green tea minimally affects biomarkers of inflammation in obese subjects with metabolic syndrome. Nutrition 2011;27:206-213.

10. Hummel S, Pfuger M, Kreichauf S, Hummel M, Ziegler AG: Predictors of overweight during childhood in offspring of parents with type 1 diabetes. Diabet Care 2009;32:921-925.

11. El Mesallamy HO, El-Demerdash E, Hammad LN, El Magdoub HM: Effect of taurine supplementation on hyperhomocysteinemia and markers of oxidative stress in high fructose diet induced insulin resistance. Diabetol Metabol Syndr 2010;2:46.

12. Ramos AT, Cunha MAL, Sabaasrur AUO, Pires VCF, Cardoso AA, Diniz MF: Use of Passiflora edulis f. flavicarpa on cholesterol reduction. Braz J Pharmacog 2007;17:592-597.

13. Doyama JT, Rodrigues HG, Novelli EL, Cereda E, Vilegas W: Chemical investigation and effects of the tea of Passiflora alata on biochemical parameters in rats. J Ethnopharmacol 2005;96: 371-374.

14. Calderon IMP, Rudge MVC, Brasil MAM: Diabetes and experimental pregnancy in rats: I. Diabetes induction, pregnancy obtention and evolution. Acta Cir Bras 2002;7:9-14.

15. Damasceno DC, Volpato GT, Person OC, Yoshida A, Rudge MV, Calderon Ide M. Effect of acetylsalicylic acid on the reproductive performance and on offspring from wistar rats]. $\underline{\text { Rev }}$ Assoc Med Bras 2002;48:312-6. Portuguese.

16. Damasceno DC, Kempinas WG, Volpato GT, et al.: Anomalias Congênitas: Estudos Experimentais. Coopmed, Belo Horizonte, Brazil, 2008.

17. Paletas K, Athanasiadou E, Sarigianni M, et al.: The protective role of the Mediterranean diet on the prevalence of metabolic syndrome in a population of greek obese subjects. J Am Coll Nutr 2010;29:41-45.

18. Bera TK, De D, Chatterjee K, Ali KM, Ghosh D: Effect of Diashis, a polyherbal formulation, in streptozotocin-induced diabetic male albino rats. Int J Ayurveda Res 2010;1:18-24.

19. Baviloni PD, dos Santos MP, Aiko GM, et al.: Mechanism of anti-hyperglycemic action of Vatairea macrocarpa (Leguminosae): investigation in peripheral tissues. $J$ Ethnopharmacol 2010;131:135-139.

20. Umar A, Ahmed QU, Muhammad BY, Dogar BB, Soad SZ: Anti-hyperglycemic activity of the leaves of Tetracera scandens Linn. Merr. (Dilleniaceae) in alloxan induced diabetic rats. J Ethnopharmacol 2010;131:140-145.

21. Tao W, Deqin Z, Yuhong L, et al.: Regulation effects on abnormal glucose and lipid metabolism of TZQ-F, a new kind of Traditional Chinese Medicine. J Ethnopharmacol 2010;128:575582.

22. Salahuddin M, Jalalpure SS. Antidiabetic activity of aqueous fruit extract of Cucumis trigonus Roxb. In streptozotocin-induceddiabetic rats. J Ethnopharmacol 2010;127:565-7.

23. Adeneye AA, Adeyemi OO: Further evaluation of antihyperglycaemic activity of Hunteria umbellata (K. Schum) Hallier f. seed extract in experimental diabetes. $J$ Ethnopharmacol 2009;126:238-243.

24. Daisy P, Eliza J, Mohamed Farook KA. A novel dihydroxy gymnemic triacetate isolated from Gymnema sylvestre possessing normoglycemic and hypolipidemic activity on STZ-induced diabetic rats. J Ethnopharmacol 2009;126:339-344.

25. Volpato GT, Vieira FL, Damasceno DC, et al.: Effects of leaves of Polymnia sonchifolia (yacon) aqueous extract in diabetic rats. Bras J Med Plants 2007;9:88-93.
26. Fuji M, Takei I, Umezawa U: Antidiabetic effect of orally administered conophylline-containing plant extract on streptozotocin-treated and Goto-Kakizaki rats. Biomed Pharmacother 2009;1-7.

27. Kaimal S, Sujatha KS, George S: Hypolipidaemic and antioxidant effects of fruits of Musa AAA (Chenkadali) in alloxan induced diabetic rats. Ind J Exp Biol 2010;48:165173.

28. Xing XH, Zhang ZM, Hu XZ, Wu RQ, Xu C: Antidiabetic effects of Artemisia sphaerocephala Krasch. gum, a novel food additive in China, on streptozotocin-induced type 2 diabetic rats. J Ethnopharmacol 2009;125, 410-6.

29. Ghule BV, Ghante MH, Saoji AN, Yeole PG: Antihyperlipidemic effect of the methanolic extract from Lagenaria siceraria Stand. fruit in hyperlipidemic rats. J Ethnopharmacol 2009; 124:333.

30. Kiss ACI, Takaku M, Damasceno DC, et al.: Effect of Allium sativum $\mathrm{L}$. (Garlic) aqueous extract on biochemical parameters of the streptozotocin-induced diabetic rats. Bras J Med Plants 2006;8:24-30.

31. Helmstädter A, Schuster N: Vaccinium myrtillus as an antidiabetic medicinal plant-research through the ages. Pharmazie 2010;65:315-321.

32. Dhanapakiam P, Joseph JM, Ramaswamyn VK, Moorthi M, Kumar AS: The cholesterol lowering property of coriander seeds (Coriandrum sativum): mechanism of action. J Environment Biol 2008;29:53-56.

33. Barbalho SM, Spada APM, Oliveira EP, et al.: Mentha piperita effects on Wistar rats plasma lipids. Braz Arch Biol Technol 2009;52:1137-1143.

34. Visavadiya NP, Narasimhacharya AV: Asparagus root regulates cholesterol metabolism and improves antioxidant status in hypercholesteremic rats. Evidence Based Complement Altern Med 2009;6:219-226.

35. Bilanda DC, Dimo T, Dzeufiet Djomeni PD, et al.: Antihypertensive and antioxidant effects of Allanblackia floribunda Oliv. (Clusiaceae) aqueous extract in alcohol- and sucroseinduced hypertensive rats. J Ethnopharmacol 2010;128:634-640.

36. Pandit R, Phadke A, Jagtap A: Antidiabetic effect of Ficus religiosa extract in streptozotocin-induced diabetic rats. $\underline{\text { E Ethno- }}$ pharmacol 2010;128:462-426.

37. Chua M, Baldwin TC, Hocking TJ, Chan K: Traditional uses and potential health benefits of Amorphophallus konjac K. Koch ex N.E.Br. J Ethnopharmacol 2010;128:268-278.

38. Hur SJ, Lim BO, Park GB, Joo ST: Effects of various fiber additions on lipid digestion during in vitro digestion of beef patties. J Food Sci 2009;74:C653-C657.

39. Metzger BT, Barnes DM, Reed JD: A comparison of pectin, polyphenols, and phytosterols, alone or in combination, to lovastatin for reduction of serum lipids in familial hypercholesterolemic swine. J Med Food 2009;124:854-860.

40. Wu SC, Wu SH, Chau CF: Improvement of the hypocholesterolemic activities of two common fruit fibers by micronization processing. J Agricult Food Chemi 2009;57:5610-5614.

41. Bazzano LA: Effects of soluble dietary fiber on low-density lipoprotein cholesterol and coronary heart disease risk. $\underline{\text { Curr }}$ Atheroscler Rep 2008;10:473-477.

42. Yapo BM, Koffi KL: Dietary fiber components in yellow passion fruit rind-a potential fiber source. $J$ Agricult Food Chem 2008;56:5880-5883. 
43. Schreckinger ME, Lotton J, Lila MA, de Mejia EG: Berries from South America: a comprehensive review on chemistry, health potential, and commercialization. J Med Food 2010;13:233-246.

44. Wohlmuth H, Penman KG, Pearson T, Lehmann RP: Pharmacognosy and chemotypes of passionflower (Passiflora incarnata L.). Biol Pharm Bull 2010;33:1015-1018.

45. Sena LM, Zucolotto SM, Reginatto FH, Schenkel EP, De Lima TC: Neuropharmacological activity of the pericarp of Passiflora edulis flavicarpa degener: putative involvement of C-glycosylflavonoids. Exp Biol Med (Maywood) 2009;234:967-975.

46. Sunitha M, Devaki K: Antioxidant activity of Passiflora edulis sims leaves. Ind J Pharmacol Sci 2009;71:310-311.
47. Masteikova R, Bernatoniene J, Bernatoniene R, Velziene S: Antiradical activities of the extract of Passiflora incarnata. Acta Poloniae Pharmaeutica 2008;65:577-583.

48. Cravotto G, Boffa L, Genzini L, Garella D: Phytotherapeutics: an evaluation of the potential of 1000 plants. $\underline{J \text { Clin Pharmacol Ther }}$ 2010;35:11-48.

49. Zucolotto SM, Goulart S, Montanher AB, et al:: Bioassay-guided isolation of anti-inflammatory C-glucosylflavones from Passiflora edulis. Bras J Med Plants 2009;75:1221-1226.

50. Ferreres F, Sousa C, Valentão P, et al.: New C-deoxyhexosyl flavones and antioxidant properties of Passiflora edulis leaf extract. J Agricult Food Chem 2007;55:10187-10193. 
This article has been cited by:

1. A.P. Espírito-Santo, A. Lagazzo, A.L.O.P. Sousa, P. Perego, A. Converti, Maricê N. Oliveira. 2013. Rheology, spontaneous whey separation, microstructure and sensorial characteristics of probiotic yoghurts enriched with passion fruit fiber. Food Research International 50:1, 224-231. [CrossRef]

2. Sandra Maria Barbalho, Maricelma da Silva Soares de Souza, Patrícia Cincotto dos Santos Bueno, Élen Landgraf Guiguer, Flávia Maria Vasques Farinazzi-Machado, Adriano Cressoni Araújo, Carla Omete Meneguim, Eliane Pascoal Silveira, Natalia de Souza Oliveira, Beatriz Clivati da Silva, Sara da Silva Barbosa, Claudemir Gregório Mendes, Priscilla Rodrigues Gonçalves. 2012. Annona montana Fruit and Leaves Improve the Glycemic and Lipid Profiles of Wistar Rats. Journal of Medicinal Food 15:10, 917-922. [Abstract] [Full Text HTML] [Full Text PDF] [Full Text PDF with Links] 